\title{
The Structure of the Aerial Shoots of Psilotum flaccidum, Wall.
}

\author{
BY \\ W. STILES, B.A. \\ Assistant-Lecturer in Botany in the University of Leeds; formerly Scholar of Emmanuel \\ College, Cambridge.
}

With Plate $\mathbf{X X V}$.

INTRODUCTION.

T

HE genus Psilotum is generally regarded as comprising two species : Psilotum triquetrum, Sw., and P. flaccidum, Wall. The two species differ chiefly in the form of the aerial stem; in $P$.triquetrum this is multiangular in the lower parts and triquetrous in the ultimate branches, while in $P$. flaccidum the lower part is triquetrous and the upper part flattened in one plane. Each species includes a variety with more slender aerial shoots which is by many authorities regarded as a distinct species; $P$. Capillare, B1., is the variety of $P$. triquetrum, and $P$. complanatum, Sw., the variety of $P$. flaccidum. In the case of the latter $P$. complanatum is sometimes regarded as the type and $P$. flaccidum as the variety. From Baker's ${ }^{1}$ description the material here described is referable apparently to $P$. flaccidum, but the distinction between this and $P$. complanatum does not seem to be very clear.

As regards geographical distribution, according to Bertrand, ${ }^{2}$ who regards $P$. complanatum and $P$. flaccidum as distinct species, the former is found in Jamaica, Mexico, Philippine Islands, Society Isles, and Sandwich Isles, while $P$. flaccidum occurs in Java and the Philippine Islands. The material on which the following account is based was, however, collected by Professor Stanley Gardiner in the Seychelles, on the summit of Mount Sebert at an elevation of 1,800 feet, and was preserved in methylated spirit. This material consisted of the complete parts of five aerial stems, but unfortunately none of the rhizome was present. Some laboratory material of unknown origin, and which had been preserved in formalin, was also available for examination, but consisted of the upper aerial branches only. In both this material and that from the Seychelles sporangia were numerous.

1 Baker, J. G. ('87), p. 30.

${ }^{2}$ Bertrand, C. E. ('83), p. 1 I.

[Annals of Botany, Vol. XXIV. No. XCIV. April, 1910.] 
To Professor Seward my thanks are due for handing over the material to me for examination. I would also thank him and Mr. Tansley for their advice given with regard to the work and for their interest in its progress. To Mr. H. H. Thomas I am indebted for advice and help with the photomicrographs.

\section{External MoRPHOLOGY.}

The sporophyte of Psilotum flaccidum consists of a branched rhizome, certain branches of which grow out towards the surface of the substratum, and ultimately become aerial stems. As in all the Psilotaceae, there are no roots. The plant is epiphytic and of pendulous habit; its rhizome apparently grows in the humus attached to trees, from which its aerial branches hang down in clusters. ${ }^{1}$

Our knowledge of the rhizome is practically limited to the references to it in the monographs of Bertrand, ${ }^{2}$ Solms-Laubach, ${ }^{3}$ and Pritzel, ${ }^{4}$ from which it would appear to be very similar to that of P. triquetrum. The branches of the rhizome which are destined to become aerial shoots pass through a transition region before reaching the surface of the substratum.

All my five specimens of aerial shoots are from 15 to 20 centimetres long, and in each case at its very base the aerial stem is cylindrical and of a dark colour. Higher up this stem loses its dark colour and becomes wider, and soon passes over into a triquetrous region, which persists for a shorter or longer distance, and itself gradually changes into the flattened form characteristic of the greater part of the aerial branches (Pl. XXV, Fig. I). The triangular lower part and flattened upper part are clearly shown in the early figure of $P$. complanatum published by Swartz ${ }^{5}$ in 1806 .

In Psilotum triquetrum the branching is apparently dichotomous, the planes of successive dichotomies being at right angles. This would seem to be the case in $P$. flaccidum so long as the stem is triangular ${ }^{6}$ (Fig. $\mathbf{I}$ ), but where the stem is flattened the branching takes place all in one plane.

The stem bears two kinds of appendages, leaves and sporophylls. The former are small scale-like structures about a millimetre long and lanceolate in shape. The sporophylls are forked, the lower part below the two prongs being extremely short, so that the sporophyll has much the appearance of two leaves closely connate at their base. Between the two lobes of the sporophyll is the sporangiophore. This consists of a very short axis bearing at its apex the three confluent sporangia. Bilocular synangia are also by no means uncommon. ${ }^{7}$

${ }^{1}$ Pritzel, E. ('00), p. 6 ro.

4 Pritzel, E., l.c.

2 Bertrand, C. E. ('83).

${ }^{5}$ Swartz, O. (1806), pp. 188, 414, t. 4, Fig. 5.

- Branching in the triquetrous region of the stem is rare, and my specimens were few in number, so that this point could not be definitely ascertained.

${ }^{7}$ Cf. Psilotum triquetrum, Miss Ford ('04), p. 59 1. 
The leaves are borne on the ridges of the stem so that on the lower parts the leaf insertion is tristichous, and on the upper flattened parts distichous. ${ }^{1} \quad$ The sporophylls occur mostly on the upper branches, and are inserted just in the same position as the ordinary leaves. Among them, however, ordinary leaves may be scattered, while on the other hand they are not confined to this region, and are sometimes found on the lower branches. The aerial shoot, like that of $P$. triquetrum, thus exhibits the 'Selago' condition of Bower.'

The branching of the stem is apparently dichotomous, but Prantl ${ }^{3}$ showed that in P. triquetrum a leaf always occurred below the fork of the stem, and he supposed that one of the branches of the apparent dichotomy was really axillary. Solms-Laubach, on the other hand, thought that in $P$. flaccidum the leaf insertion pointed to a true dichotomy, for the alternate distichous arrangement is continued at first on the two branches taken as a whole, as if no dichotomy had occurred, while the distichous arrangement on each branch is assumed higher up. ${ }^{4}$ In my material of $P$. flaccidum there was constantly a leaf associated with the branching, although this was sometimes carried up, presumably by later intercalary growth, on to one of the branches. This point will be referred to subsequently.

A single cylindrical stele traverses the stem and bifurcates with the latter. In many cases a vascular bundle is given off from the stem-stele to the leaves, though this is not always so. This would appear also to be much the same as in the case of $P$. triquetrum, ${ }^{5}$ though, as many writers have stated that the leaves are without any vascular supply whatever in the latter species, leaf-traces are apparently of very much rarer occurrence in it. In $P$. flaccidum, as in P. triquetrum, the sporophyll is always served with a vascular supply.

\section{INTERNAL STRUCTURE.}

I. Stem. At the lowest parts of the stems of which my material was composed, in what Miss Ford ${ }^{6}$ describes for $P$. triquetrum as the intermediate region between rhizome and aerial stem, the branch is circular in transverse section and externally smooth and of a dark colour. The single stele is circular or somewhat elliptical in transverse section, and is surrounded by an endodermis which, although not very well differentiated, is yet clearly visible when suitably stained, its radial walls taking a lignine stain in some degree. The xylem consists of a band-shaped mass, generally with smaller protoxylem-groups at each end of the band, though sometimes these protoxylem-groups are not obvious. The whole of the xylem between the two protoxylems is composed of tracheae with scalariform

1 Cf. Solms-Laubach ('84), p. 164.

3 Prantl, K. ('76), p. $9^{2}$.

${ }^{5}$ Pritzel, E. ('00), p. 6 I6.
2 Bower, F. O. ('08), pp. $16_{5}, 4^{12}$.

4 Solms-Laubach ('84), p. $16_{5}$.

${ }^{6}$ Miss Ford ('04), p. 598. 
thickenings; no parenchymatous elements or sclerenchymatous fibres are here found among the tracheae.

Surrounding this xylem-mass is a zone of thin-walled tissue, in which are scattered more xylem-elements (Fig. 2). These latter are in the form of an irregular broken ring, and are undoubtedly of the same nature as the secondary tracheae discovered and described by Boodle ${ }^{1}$ in Psilotum triquetrum, and which have also been recorded as occurring in that species by Miss Ford. Their radial arrangement in P. faccidum is in some cases quite as obvious as in the other species, though perhaps in none of my preparations were they so numerous as in those figured by Boodle. As this author found in P. triquetrum, so in P. flaccidum there is no sign of a definite cambium.

Surrounding the zone of secondary xylem-elements is a band of thinwalled elements presumably of the nature of phloem, but this tissue is very difficult to recognize, especially in transverse sections. There is no welldefined pericycle.

The cells of the inner cortex have their walls much thickened by a brown substance (Fig. 3) which is laid down apparently more or less irregularly. ${ }^{2}$ The cell-walls decrease in thickness as the exterior of the stem is approached. The epidermis is one cell wide and has a thick cuticle. In the subterranean part of the stem stomata were not found.

As one passes up the stem it becomes wider in diameter, as does also the central stele, which also becomes more completely circular in transverse section. The two protoxylem-groups at each end of the band become more distinct, while a third protoxylem arises between them on the outside of the metaxylem, and eventually the stele becomes triangular in outline (Fig. 3). An exactly similar state of affairs is found in P. triquetrum. ${ }^{3}$ In this part of the stem there is a tendency in places to a slight mesarch structure, ${ }^{4}$ the protoxylem-elements being found not quite at the ends of the xylem arms. The secondary tracheides here begin to diminish in amount, so that when a point is reached where the stem is triquetrous they have almost completely disappeared. When the stem becomes triangular three more protoxylem-groups make their appearance between the three already present, so that with a triquetrous stem is associated a hexarch stele (Fig. 4). Mesarch structure is here sometimes very marked, and in some cases is certainly due to the insertion of a leaf-trace (Fig. 5), though at other times no leaf-trace is given off. The question of mesarchy will be discussed subsequently.

1 Boodle, L. A. ('04), p. 505.

2 Mr. Brooks has pointed out to me that in $P$. triquetrum this substance is often laid down spirally on the longitudinal walls. In all cases examined in P. faccidum the thickening due to this substance was reticulate. Sometimes, however, it seemed probable that the first layers of the substance were laid down spirally.

3 Boodle, L. A. ('04), p. 5 I 4 .

4 Cf. P. triquetrum, Boodle, L. A., 1. c. 
At about the same level as that at which the stele begins to be hexarch, fibres similar to those found in $P$. triquetrum appear in the middle of the xylem. The simple pits in the walls of the fibres are easily seen. Occasionally parenchymatous cells are found among the tracheides (Fig. 4), and sometimes gaps may occur in the xylem-ring. The endodermis also becomes much clearer, and the thickenings on the radial walls are shown up very distinctly in sections stained with methyl violet and Bismarck brown.

The cortex becomes more or less differentiated into an inner zone with fairly thin cell-walls, a middle zone of parenchymatous cells with somewhat thicker walls, and an outer assimilating layer. The epidermis here has numerous stomata.

In this region of the stem the structure is therefore very similar to that of $P$. triquetrum.

Sooner or later the number of protoxylems of the stele increase in preparation for the first bifurcation of the stem, where in all my specimens the fibres in the middle of the stem disappear. A leaf was constantly associated with this bifurcation, and in all cases examined received a vascular supply, such that practically one-half of the divided stemstele was in the axil of the leaf-trace. Sometimes this leaf was carried up on to the fork of the stem above the bifurcation, but when this was the case its vascular supply originated in connexion with the bifurcation of the stem-stele.

In the branches of a higher order central fibres were not observed, while in the flattened branches the number of protoxylem groups was constantly four, two of the six xylem arms of the triquetrous stems gradually dying out. Thus in P. flaccidum, except in the region of a bifurcation, and in the transitional region between the triangular and flattened stems, the number of xylem arms would appear to be double the number of ridges on the stem. ${ }^{1}$ This is apparently a different state of affairs to that found in $P$. triquetrum, where any close connexion between the number of protoxylem-groups and the number of ridges on the stem is not evident. The relationship in $P$. flaccidum is, moreover, often masked owing to the early preparation for the bifurcation of the stele.

The xylem in the flattened branches occupies the centre of the cylindrical stele, and is cruciform as seen in transverse section, the four protoxylem-groups occurring at the end of each arm near the endodermis, so that the stele is here quite exarch (Fig. 6). The tetrarch arrangement was obvious in the smaller sporangiferous branches.

The protoxylem consists of a few tracheidal elements at the ends of the xylem arms with spiral thickenings on their walls. The metaxylem-

1 The transitional region between the hexarch and tetrarch stele is, however, generally of much greater extent than that between the triquetrous and flattened stem. 
elements have scalariform thickenings, and gradually increase in size from the protoxylem inwards. Transitions between spiral and scalariform thickenings occur. As in the lowest part of the aerial stem, parenchyma and fibrous elements are usually not present in the xylem except in the very young stems below the growing point, where the elements that will form the metaxylem are as yet undifferentiated.

Extending round the xylem is a mass of thin-walled tissue, presumably of the nature of phloem. No lignification of the elements, such as occurs in Tmesipteris, ${ }^{1}$ could be noticed, but in some cases, though by no means in all, the phloem cells were lignified slightly at the corners, as in $P$. triquetrum. $^{2}$

This phloem tissue appears to be composed of two kinds of elements. In longitudinal section all the cells appear elongated, but some are much longer than the others and contain abundant contents, among the latter being numerous highly refractive globules, no doubt similar to those occurring in the sieve-tubes of Ferns described by Poirault ${ }^{3}$ (Fig. 7). They are quite obvious in unstained sections, and show up very distinctly in sections stained with ruthenium red. The elements containing these globules would presumably correspond to sieve-tubes, but not the slightest sign of callus could be found on staining with London blue or corallin soda, though this apparent absence might be due to the use of spirit material. The cross walls of these elements were sometimes very oblique, and sometimes practically at right angles to the longitudinal walls; in some cases the highly refringent globules were observed to be clustered against the wall, but in no case were sieve-plates observed. Nuclei were generally, but not always, absent from these cells, and in one case a disorganizing nucleus was observed.

Associated with these cells, and as a rule outnumbering them, are other elements of about the same diameter, but not so long. In these a large nucleus is always present, which often, but not always, presents a more or less elongated shape. From this account it will be seen that on the whole the phloem of $P$. flaccidum is very similar to that of $P$. triquetrum. ${ }^{4}$ In the phloem of Tmesipteris, however, Miss Sykes ${ }^{5}$ records sieve-tubes only, and these differ from those of Psilotum in having lignified walls and numerous lateral sieve-plates on them.

Surrounding the stele is the endodermis, which, as in the triquetrous region of the stem, forms a well-defined layer; its radial walls show their lignification plainly when stained with methyl violet and Bismarck brown.

Immediately outside the bundle, and completely surrounding it, is a cylindrical band of rather large cells, which often have thick walls. The

1 Sykes, M. G. ('08), p. 70.
${ }^{3}$ Poirault, G. ('93), p. I39.
5 Sykes, M. G., l.c.
2 Ford, S. O. ('04), p. 593.

4 Ford, S. O., 1. c. 
central part of the walls of these cells appears to be much more lignified than the part bordering on the lumen, which in some cases would appear not to be lignified at all. The cells are elongated longitudinally, and have pointed ends, the latter being much more lignified than the rest of the wall. Simple pits are very numerous on the walls of these cells, and are easily observed.

On the narrow diameter of the stem the thickened layer abuts directly on the chlorophyllous assimilating layer (Fig. 8). This extends completely round the stem as a layer of from two to four cells wide just inside the epidermis, and filling up all the space between the epidermis at the ends of the longer diameter of the latter. In longitudinal section these cells show the peculiar shape already noted for those of this tissue in P. triquetrum. ${ }^{1}$ The walls are thin and wavy in contour, touching the adjacent cells in three or four places only, so that intercellular spaces between the cells are large and numerous.

Between the chlorophyll-containing tissue in the wings and the fibrous layer round the bundle are parenchymatous cells, which pass gradually into the latter.

The epidermis is a single layer of regular cells with a very thick outer wall; as in $P$. triquetrum ${ }^{2}$ the innermost layer of the outer wall is not cuticularized, while the outer layers become more cuticularized the further they are from the inner one. Under high magnifications the layering of the outer wall is very distinct. The epidermal cells are somewhat elongated longitudinally.

Stomata are numerous, as would be expected in an assimilating stem ; they are sunk somewhat below the outer level of the epidermis. They are somewhat peculiar in shape, there being only a single ridge on each guard-cell, a state of affairs which is somewhat rare. ${ }^{3}$ In $P$. triquetrum, according to De Bary, both ridge of entrance and ridge of exit are absent.

2. Leaf-trace. When a leaf-trace is given off from the stele the xylem arm on the side of the leaf becomes elongated, and ultimately two or three tracheides, or sometimes more, are detached, which pass up to the leaf, making an angle of about $30^{\circ}$ with the main stele (Fig. 9). These tracheae are small, and have spiral or scalariform thickenings on their walls. As a rule the number of elements is too small to enable one to determine the position of the protoxylem. Surrounding the tracheae are some elongated thin-walled cells continuous with those of the phloem of the stem-stele. In some cases a distinct endodermis was observed.

3. The Leaf. The leaves are small lanceolate structures about one millimetre long, and similar in shape to those of P. triquetrum (Fig. IO). There is an epidermis with a very thick cuticle, this layer being continuous

$$
{ }^{1} \text { Ford, S. O. ('04), p. } 59^{2} . \quad{ }^{2} \text { De Bary, A. ('84), p. } 77 .
$$


with that of the stem. Stomata were not observed, and Miss Ford states that they are absent from the leaf of $P$. triquetrum. The interior of the leaf is composed of parenchymatous cells continuous with the assimilatory tissue of the stem. The cells in the leaf, however, do not possess to any marked degree the intercellular spaces characteristic of the outer cortical cells of the stem, and in this respect the leaf differs from that of P. triquetrum. They contain, however, conspicuous nuclei and many chloroplasts.

The leaf-trace, the xylem of which, when it exists, terminates at the level of the leaf insertion, is continued into the leaf by some narrow elongated cells. These appear to be completely absent from the leaves of $P$. triquetrum.

4. The Sporophyll. The forked sporophyll has almost exactly the same structure as two scale leaves connate at the base. Transitions between ordinary leaves and sporophylls are found in which the leaf is divided for a part only of its length.

Between the two prongs of the forked sporophyll arises the sporangiophore, which consists of a short axis bearing, and completely fused with, a synangium of three confluent sporangia. In all cases examined a vascular bundle supplied the spore-producing member. As a rule about two or three tracheides are given off from the ends of one of the xylem arms of the stem-stele in exactly the same way as the leaf-trace originates. The sporophyll-trace (Fig. II) passes up through the cortex in much the same way as the leaf-trace, and elongated parenchymatous cells pass into the two forks of the sporophyll as into the leaf. The xylem does not, however, terminate at the level of insertion of the sporophyll, but passes up into the axis of the sporangiophore. Here the number of xylem-elements increases, so that a section passing transversely through the three loculi also passes through a vascular bundle in the axis between them, composed of five to eight tracheae. These, however, terminate below the middle of the synangium.

Bertrand ${ }^{1}$ states that in $P$. triquetrum the axis of the synangium is completely without vascular tissue, although elongated cells are present here.

The vascular structure of the sporangiophore found in $P$. flaccidum is interesting in comparison with Tmesipteris. In Tmesipteris Miss Sykes ${ }^{2}$ found the sporophyll bundle divided into three, the two lateral strands passing one into each lobe of the forked sporophyll, the central strand passing into the axis of the sporangiophore. This is similar to what takes place in $P$. flaccidum, only here the sporophyll bundles, like the leaf bundles, are represented by a few elongated parenchymatous cells.

The bundle in the axis of the sporangiophore of Tmesipteris then divides into three at the base of the bilocular synangium; the two lateral

\footnotetext{
1 Bertrand, C. E. ('83), p. 2 I 3 .
} 
ones pass round the outside of the septum, the middle one passes a short way into the septum. In $P$. flaccidum the central bundle, which passes into the middle of the tissue between the three loculi, corresponds to the bundle in Tmesipteris that passes into the septum, while no representative of the two lateral branches is to be found.

The structure of the synangium seems otherwise identical with that of $P$. triquetrum, and therefore need not be further discussed here.

\section{General Considerations.}

From the present investigation it will be seen that Psilotum flaccidum closely resembles $P$. triquetrum in internal structure. In the occasional occurrence of very distinct mesarch xylem, in the more general presence of leaf-traces, and in the presence of a vascular bundle in the axis of the sporangiophore, $P$. flaccidum approaches Tmesipteris more nearly than does the other species, and in these respects serves as a connecting link.

It is a difficult question to decide which of these three species approaches most nearly the ancestral type from which they all sprang. The most general opinion is that they are all reduced forms in accordance with their epiphytic habit, yet Bower, ${ }^{1}$ though he does not dispute this reduction theory, on the other hand does not seem inclined to accept it, and leaves it an open question, while Lignier ${ }^{2}$ regards the Psilotaceae as very primitive.

So far as regards the structure of the Psilotaceae, there is little evidence obtainable in support of either view. The feeble development of secondary wood in the base of the aerial stem in both $P$. flaccidum and $P$. triquetrum might be used as an argument in favour of reduction, but it might also be regarded as having originated independently in the genus, especially as Miss Sykes, ${ }^{3}$ in spite of careful search, failed to find any trace of it in Tmesipteris. The rootless condition of the plant may also be due to reduction, and this seems the more probable when its peculiar epiphytic habit is considered.

The same question of primitiveness or reduction arises when the microphylly of Psilotum is considered. Jeffrey ${ }^{4}$ and Lignier ${ }^{5}$ regard the Psilotaceae as primitively microphyllous forms connected with the Lycopodiales, the first-named writer also associating the Equisetales with them. The general opinion is, however, that the leaves are reduced structures. In this connexion the occasional occurrence of mesarch xylem in both $P$. triquetrum and $P$. flaccidum may be of importance. Boodle ${ }^{6}$ thinks that "the most natural conclusion is that the aerial stem of Psilotum has

\footnotetext{
1 Bower, F. O. ('08), p. 4' 3.

3 Sykes, M. G. ('08), p. 78.

${ }^{5}$ Lignier, O. ('03), l.c.
}

${ }^{2}$ Lignier, O. ('03), p. 95.

4 Jeffrey, E. C. ('02), p. I 44.

6 Boodle, L. A. ('04), p. $5^{\text {I } 4}$. 
been reduced from the mesarch to the exarch type in connexion with the disappearance of the leaf-traces'. Miss Sykes ${ }^{1}$ holds a similar view, for she thinks mesarch structure in Tmesipteris and exarch structure in Psilotum are to be explained as due to the different size of the leaves in the two genera.

The occurrence of very marked mesarchy in connexion with the insertion of a large leaf-trace in $P$. flaccidum appears to me to lend support to this view.

Boodle also considers that the secondary thickening in Psilotum is reduced from the more normal type, and is to be correlated with the reduction of the leaves to scales, thus causing a diminution of transpiration. ${ }^{2}$ This writer's views appear to me to offer the most likely explanation of the secondary thickening and occasional mesarchy in Psilotum, but it should not be forgotten that these features can be explained as primitive structures, and not as due to reduction.

There remains to be considered the question of the spore-producing member. Scott ${ }^{3}$ and Bower ${ }^{4}$ regard the sporophyll as foliar, the former writer considering the sporangiophore in Psilotum as part of the sporophyll of which it is an adaxial outgrowth, and which thus occupies a similar position to the sporangiophores of the Sphenophyllales. Bower limits the term sporophyll to the forked bract, the sporangiophore borne on it being non-foliar in nature; it is here associated with the subtending sporophyll, but in other groups may be quite independent of it.

Bower considers the sporangiophore as an organ sui generis. The sporophyll he regards as a modified foliage leaf.

Miss Sykes, ${ }^{5}$ adopting the view of Strasburger, Goebel, and Bertrand, regards the sporangiophore as a branch of the main axis bearing two leaves (the forked 'sporophyll') and terminating, in the case of Psilotum, in three confluent sporangia. Her chief argument in favour of this view is based on the fact that in Tmesipteris the bundle in the axis of the sporangiophore, after giving off a strand on either side into the lobes of the sporophyll, is continued into the septum, a branch being again given off on each side which runs round the periphery of the septum. The central strand, Miss Sykes thinks, may terminate the axis of the sporangial branch.

I find myself unable to accept this view. It has been shown that a bundle corresponding to the central one in Tmesipteris is also present in Psilotum flaccidum, and here it seems simply to serve as a vascular supply to the synangium. Miss Sykes herself seems to regard the lateral bundles in Tmesipteris as serving the purpose of supplying the large masses of developing spores with plentiful supplies of food and water, ${ }^{6}$ and there

\footnotetext{
${ }^{1}$ Sykes, M. G. ('08), p. 77.

${ }^{3}$ Scott, D. H. ('07).

${ }^{5}$ Sykes, M. G. ('08).
}

2 Boodle, L. A. ('04), p. 5 II.

${ }^{4}$ Bower, F. O. ('08), p. $4^{26 .}$

${ }^{6}$ Sykes, M. G. ('08), p. 80. 
seems no reason against supposing that these lateral branches have gradually replaced an original single central one. Moreover, in Psilotum ordinary leaves and sporophylls occur in exactly similar positions with regard to the axis, and sporophylls may take the place of leaves on the lower parts of the shoot, and leaves may replace sporophylls on the upper part. Again, the vascular supply of leaves and sporophylls in P. flaccidum arises in exactly the same way from the stele of the main axis. These facts all point to the homology of the sporophyll with the ordinary leaf.

As to the morphological value of the sporangiophore of the Psilotales, I share the feeling expressed by $\mathrm{H}$. $\mathrm{H}$. Thomas ${ }^{1}$ with regard to this organ in the Equisetales, namely, that the evidence derived from the group under consideration is not conclusive in favour of any of the theories advanced to explain its nature.

\section{Systematic Position of the Psilotaceae.}

Recent views on the affinities of the Psilotaceae have lately been brought together so thoroughly by Lady Isabel Browne, ${ }^{2}$ that it will be unnecessary to restate them all in detail, though it may perhaps be as well to emphasize some points in this connexion.

For long a relation between the Lycopodiales and Psilotaceae was recognized, so that the latter order was included in the former class. This resemblance is closest between Lycopodium and Psilotum, both genera having exarch protosteles, while lately an occasional occurrence of mesarchy has been observed in Lycopodium ${ }^{3}$ as well as in Psilotum. The mode of branching is considered as dichotomous in both genera, both are microphyllous, and in the Psilotaceae the relation of the sporangiophore to the sporophyll is similar to that of the sporangium to the sporophyll in the Lycopodiales. If Lang's prothallus referred provisionally to Psilotum ${ }^{4}$ actually belongs to that plant, it furnishes additional evidence of this relationship, for it is very similar to the prothallus of Lycopodium clavatum.

In $1897 \mathrm{Scott}^{5}$ pointed out the close resemblance existing between the sporangiophores of the Psilotaceae and those of the Sphenophyllales. This resemblance is shared by anatomical characters, for the stele of Sphenophyllum consists generally of a triquetrous exarch protostele with three protoxylem-groups, though sometimes each protoxylem-group is replaced by two. The normally exarch stele of Psilotum recalls that of Sphenophyllum, while the repetition of the triquetrous condition in the base of the aerial stem of $P$. triquetrum, ${ }^{6} P$. flaccidum, and Tmesipteris, ${ }^{7}$ and in

1 Thomas, H. H. ('09), p. $25^{8}$.

${ }^{3}$ Sinnott, E. W. ('09), p. I 38 .

${ }^{5}$ Scott, D. H. ('97), p. 27.

7 Dangeard, P. A. ('91), Pl. XII, Fig. Io.
2 Browne, Lady Isabel ('09), p. I I 4 .

4 Lang, W. H. ('04), p. 57 I.

6 Boodle, L. A. ('04), p. 5I 4 . 
the smaller branches of the first species is at any rate interesting. The feeble secondary thickening in both species of Psilotum also recalls the normal secondary growth of wood in Sphenophyllum. As regards stem anatomy the comparison of Tmesipteris has been rather with Cheirostrobus, where mesarch xylem sometimes occurred. In this respect Psilotum probably approaches Cheirostrobus more nearly than Tmesipteris.

Scott's view has been adopted by A. P. W. Thomas ${ }^{1}$ and Bower, ${ }^{2}$ who go further than Scott and place the Psilotaceae as an order of the Sphenophyllales. The chief arguments against the view are to be found in the phyllotaxis and in the mode of branching. In the Sphenophyllales the leaves are borne in whorls, and from the constancy of the character throughout the group, $\mathrm{Scott}^{3}$ is inclined to attach much importance to it. In the Sphenophyllales the branching was axillary, while in the Psilotaceae it is dichotomous. But as Bower ${ }^{4}$ points out, branching is axillary in the Equisetales, yet dichotomy may occasionally occur, and it is easy to imagine that a group where both modes of branching were possible might give rise to one line of descendants where axillary branching prevailed, and to another where the branching was dichotomous.

Moreover, it seems to be not impossible that the branching in Psilotum is either now axillary, as Prantl supposed, or has been derived from an axillary mode of branching. The constant relation of a leaf to the stem bifurcation seems to me to support this opinion. This would remove one of the chief differences between the Psilotaceae and the Sphenophyllales, and in any case the fairly near relationship of the two groups seems to be almost proved. On the other hand, the resemblances between the Psilotaceae and the Lycopodiales seem too great to warrant the present tendency to separate the two phyla widely, and to me the most logical position appears to be that of Scott in $1907,{ }^{5}$ in which he regards the Psilotales as having most in common with the Sphenophyllales, but as possessing also some of the Lycopodineous affinities that have been previously attributed to them.

Lignier ${ }^{6}{ }^{6}$ however, holds a very different view. To him the Psilotaceae are primitive types allied to the Lycopodiales, while the Sphenophyllales are related to the primitive Fern stock through Archaeopteris. Further back still the Lycopod phylum and Fern phylum are connected, the common ancestor consisting of a dichotomizing axis bearing small appendages or phylloids. These are represented to-day in the leaves of the Psilotaceae and Lycopodiales. In the Fern phylum branches of the axis were specialized for assimilatory purposes and became leaves. ${ }^{7}$ Thus, on Lignier's view, the leaves of the Psilotaceae and Sphenophyllales are not homologous, and

1 Thomas, A. P. W. ('02), p. $35^{\circ}$.

Scott, D. H. ('07), p. I66; ('09), p. 626.

${ }^{5}$ Scott, D. H. ('07), p. 166.

${ }^{7}$ Cf. Tansley, A. G. ('08), p. 6.
2 Bower, F. O. ('08), p. 423.

4 Bower, F. O. ('08), p. 424.

- Lignier, O. ('03), p. 95; ('08), p. 278. 
the two groups are connected so far back that the gap between them is about as great a one as exists between any two groups of the Pteridophyta. The arguments against Lignier's view have been put forward very clearly by Lady Isabel Browne, ${ }^{1}$ and it is unnecessary to repeat them here. The suggestion of an axillary mode of branching in the Psilotaceae might, however, add another objection to the list, and the resemblance between the Psilotaceae and Sphenophyllales appear too pronounced to warrant their distant separation.

It seems to me quite possible that the Psilotaceae may connect the Sphenophyllales and Lycopodiales, while at the same time Archaeopteris may be a connecting link between the Sphenophyllales and the Ferns. It should, however, be noted that Kidston ${ }^{2}$ regards the Archaeopterideae as Pteridosperms and not Ferns at all. Moreover, it must be admitted that our knowledge of Archaeopteris is so slight that this form can at present be of little use in phylogenetic considerations.

In any case, whether the Psilotaceae are reduced or primitive, the evidence at present available seems to indicate a relationship between these forms and the Sphenophyllales, and also, though less marked, with the Lycopodiales.

\section{SUMMARY.}

I. In external appearance the aerial stems of Psilotum flaccidum differ from those of $P$. triquetrum in being rounded below, triquetrous above this, and ultimately flattened. In the triquetrous region branching probably takes place in planes successively at right angles; in the flattened part branching is all in one plane. A leaf seems to be constantly associated with stem bifurcation.

2. The stem-stele is band-shaped in the lowest part of the aerial shoot, but becomes triquetrous. When the stem is triquetrous the xylem-mass is typically hexarch; in the flattened parts the stele changes from a hexarch to a tetrarch condition.

3. The leaves often receive a vascular supply, and when this is the case with a leaf below the stem fork, the leaf-trace is given off so that one branch of the stele is practically in the axil of the leaf-trace.

4. Secondary thickening similar to that found in P. triquetrum is also found in P. flaccidum.

5. Mesarch structure occurs occasionally in the lower part of the aerial stem, sometimes in connexion with the leaf-traces.

6. The sporangiophore-trace is given off in the same manner as a leaftrace. It is continued into the sporangiophore, and terminates in the central tissue between the three confluent sporangia. It is thus similar in position to the median bundle in the synangium of Tmesipteris.

1 Browne, Lady Isabel ('09), p. I I 5 .

${ }^{2}$ Kidston, R. ('06), p. 434 . 
7. The sporophyll is probably homologous with a foliage leaf. The evidence is insufficient to decide whether the sporangiophore is foliar in nature or is an organ sui generis.

8. The Psilotales are probably allied to the Sphenophyllales and Lycopodiales, but show greater resemblances to the former.

Botany School, Cambridge.

\section{LITERATURE CITED.}

BAKER, J. G.: Handbook of the Fern Allies. London, I887.

BARY, A. DE: Comparative Anatomy of the Vegetative Organs of the Phanerogams and Ferns English edition, Oxford, 1884.

Bertrand, C. E.: Recherches sur les Tmésiptéridées. Lille, I883. (Originally published in Archives bot. du Nord de la France, I881-3. The references in the text refer to the separate monograph.)

Boodle, L. A.: On the Occurrence of Secondary Xylem in Psilotum. Annals of Botany, xviii, I904, p. 505 .

Bower, F. O.: The Origin of a Land Flora. London, I908.

Browne, LAdy IsABeL: The Phylogeny and Inter-relationships of the Pteridophyta. New Phytologist Reprint, Cambridge, I909.

Dangeard, P. A. : Mémoire sur la Morphologie et l'Anatomie des Tmesipteris. Le Botaniste, ii, 189 I, p. 163 .

Ford, Miss S. O.: The Anatomy of Psilotum triquetrum. Annals of Botany, xviii, 1904, p. $5^{89}$.

Jefrrey, E. C.: The Structure and Development of the Stem in the Pteridophyta and Gymnosperms. Phil. Trans. Roy. Soc. London, Series B, cxcv, 1902, p. II 9 .

KIDston, R.: On the Microsporangia of the Pteridospermae, with Remarks on their Relationship to Existing Groups. Phil. Trans. Roy. Soc. London, Series B, cxcviii, 1906.

LANG, W. H. : On a Prothallus provisionally referred to Psilotum. Annals of Botany, xviii, I904, p. $57 \mathrm{r}$.

Lignier, O.: Équisétales et Sphénophyllales : leur origine filicinéenne commune. Bull. de la Soc. Linn. de Normandie, $5^{\circ}$ sér., vii, 1903 , p. 93.

- : Sur l'origine des Sphénophyllales. Bull. de la Soc. Bot. de France, lv, 1908, p. 278.

Poirault, G.: Recherches anatomiques sur les cryptogames vasculaires. Annales des Sciences Naturelles, $7^{\ominus}$ sér., Botanique, xviii, I893, p. II 3 .

Prantl, K.: Bemerkungen über Verwandtschaftsverhältnisse der Gefässcryptogamen und den Ursprung der Phanerogamen. Verhandl. der physic-medic. Gesellsch. zu Würzburg, 1876 .

Pritzel, E. : in Engler and Prantl, Die natürlichen Pflanzenfamilien, I. iv. Leipzig, I900.

ScotT, D. H. : On the Structure and Affinities of Fossil Plants from the Palaeozoic Rocks. I. On Cheirostrobus, a New Type of Fossil Cone. Phil. Trans. Roy. Soc. London, Series B, clxxxix, I897.

- The Present Position of Palaeozoic Botany. Progressus Rei Botanicae, i, Heft I, 1907.

: Studies in Fossil Botany. Second edition, London, I909.

Sinnotr, E. W.: On Mesarch Structure in Lycopodium. Botanical Gazette, xlviii, I909, p. I38.

Solms-Laubach, Graf H. : Der Aufbau des Stockes von Psilotum triquetrum und dessen Entwickelung aus der Brutknospe. Ann. du Jard. Bot. de Buitenzorg, iv, I884, p. I39.

Swartz, O.: Synopsis Filicum, earum Genera et Species systematica complectens. Adjectis Lycopodineis. Kiliae, 1806 . 
Sykes, Miss M. G.: The Anatomy and Morphology of Tmesipteris. Annals of Botany, xxii, I908, p. 63 .

TAnsley, A. G.: The Evolution of the Filicinean Vascular System. New Phytologist Reprint, Cambridge, 1908.

Thomas, A. P. W.: The Affinities of Tmesipteris with the Sphenophyllales. Proc. Roy. Soc., lxix, 1902, p. 343 .

Thomas, H. H. : On a Cone of Calamostachys Binneyana (Carruthers) attached to a Leafy Shoot. New Phytologist, viii, 1909, p. 249.

\title{
EXPLANATION OF PLATE XXV.
}

\author{
Illustrating Mr. Stiles's Paper on Psilotum flaccidum.
}

Fig. I is from a photograph by W. Tams of Cambridge.

Fig. I. Part of aerial stem of Psilotum flaccidum. Natural size.

Fig. 2. Transverse section of the base of the aerial stem of P. flaccidum, showing secondary xylem elements. $x$ II 7 .

Fig. 3. Transverse section of the stem, showing triquetrous stele.

Fig. 4. Transverse section of triquetrous stem with hexarch xylem. In the middle of the xylem are some fibres, while a few parenchymatous cells also occur in the xylem.

Fig. 5. Transverse section through the end of a xylem arm of the stele, showing very distinct mesarch structure. $\times 176$.

Fig. 6. Transverse section through a flattened branch with tetrarch stele.

Fig. 7. Phloem in longitudinal section.

Fig. 8. Epidermis and assimilating layer of stem in transverse section. $\times 160$.

Fig. 9. Transverse section showing bifurcation of tetrarch stele with leaf-trace on one side about to be detached. $x$ ir 7 .

Fig. 10. Longitudinal section of the leaf. $\times 57$.

Fig. II. Sporophyll-trace in transverse section. $\times 176$. 

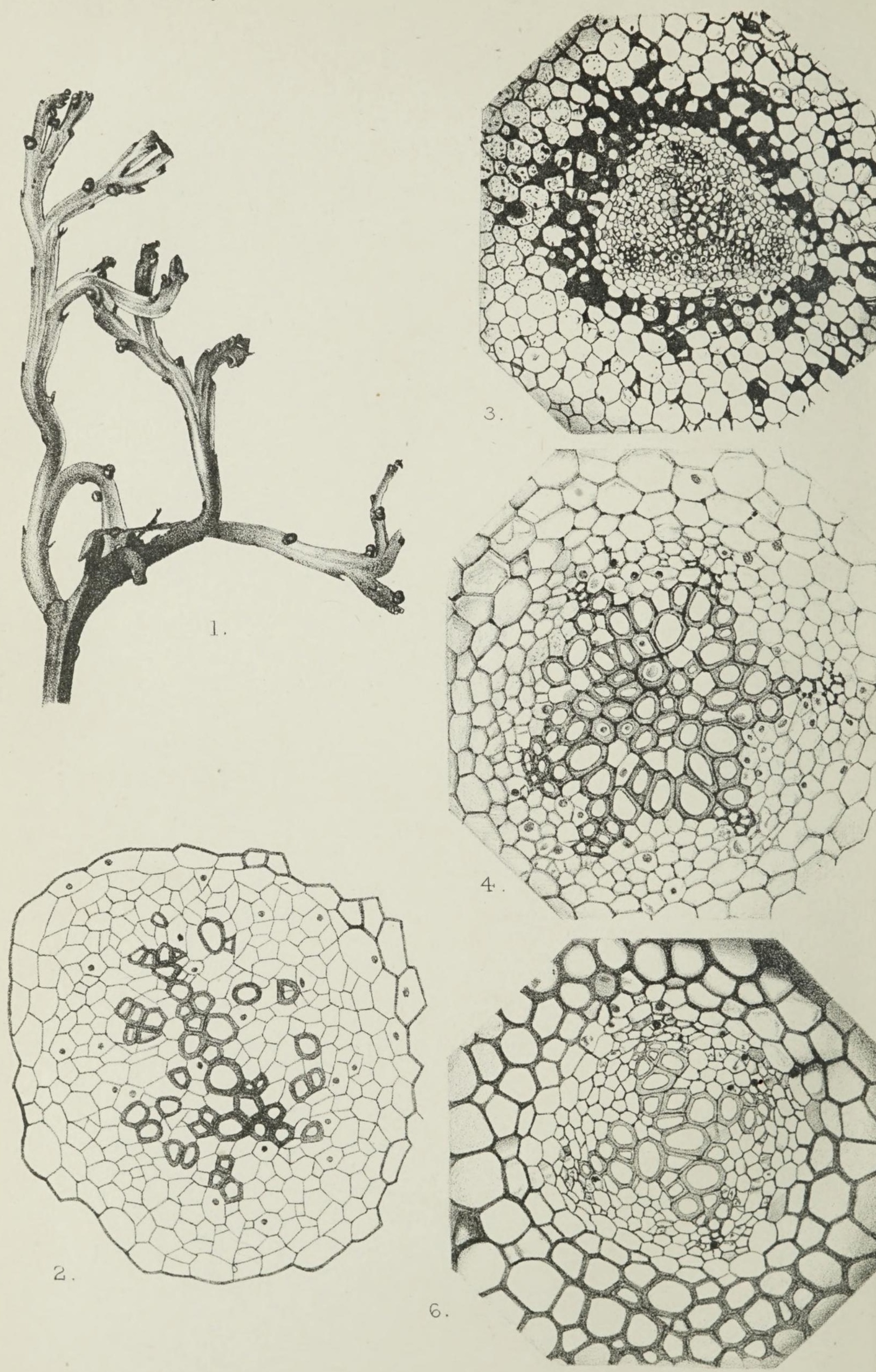

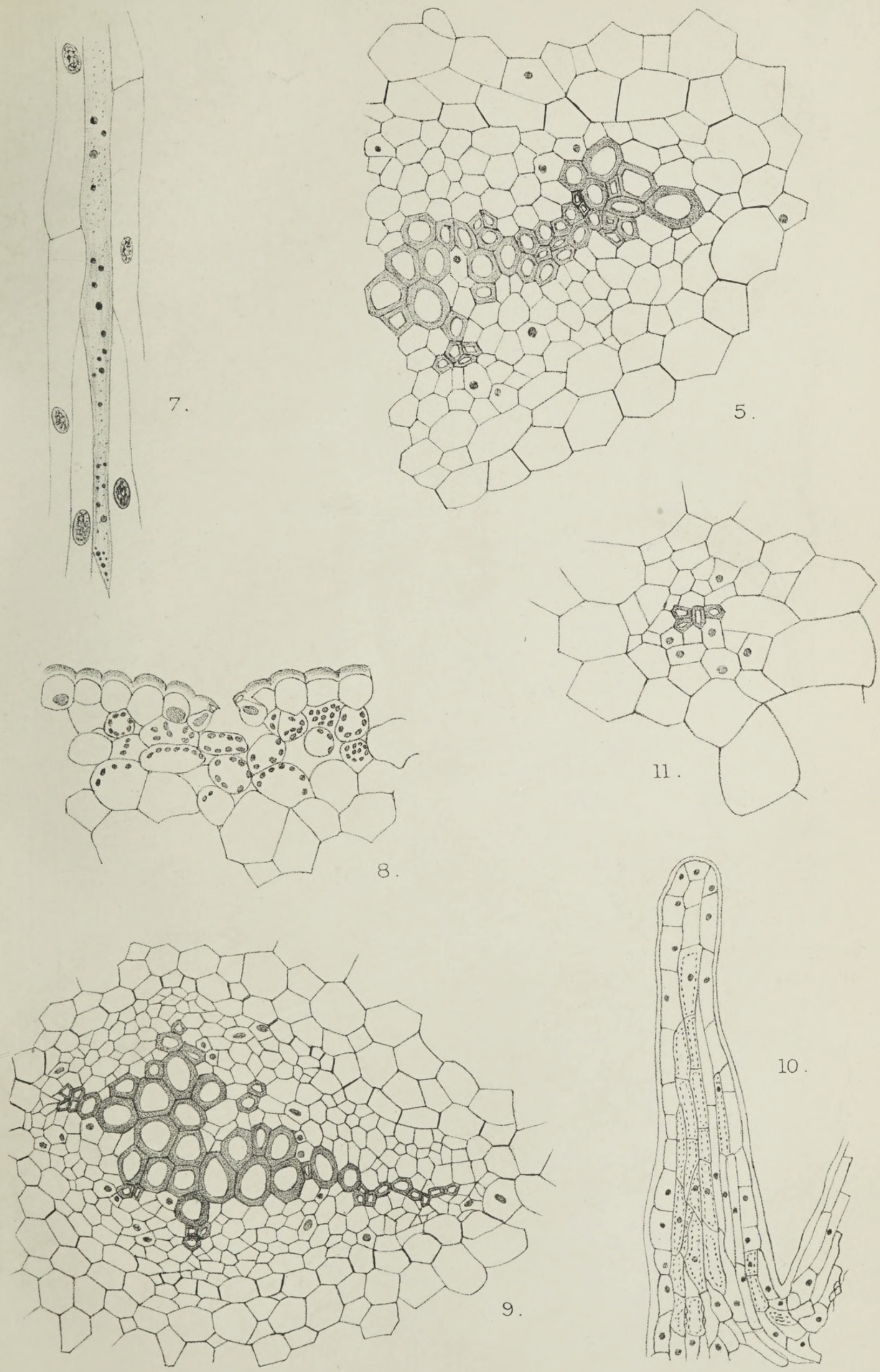


\section{$2 \mathrm{BHL}$ Biodiversity Heritage Library}

Stiles, Walter. 1910. "The structure of the aerial shoots of Psilotum flaccidum, Wall." Annals of botany 24, 373-387.

https://doi.org/10.1093/oxfordjournals.aob.a089273.

View This Item Online: https://www.biodiversitylibrary.org/item/262605

DOI: https://doi.org/10.1093/oxfordjournals.aob.a089273

Permalink: https://www.biodiversitylibrary.org/partpdf/319781

\section{Holding Institution}

New York Botanical Garden, LuEsther T. Mertz Library

\section{Sponsored by}

BHL-SIL-FEDLINK

\section{Copyright \& Reuse}

Copyright Status: Public domain. The BHL considers that this work is no longer under copyright protection.

This document was created from content at the Biodiversity Heritage Library, the world's largest open access digital library for biodiversity literature and archives. Visit BHL at https://www.biodiversitylibrary.org. 